\title{
Atmospheric levels of BTEX compounds during the 2008 Olympic Games in the urban area of Beijing
}

\author{
Junfeng Liu ${ }^{a}$, Yujing Mu ${ }^{\text {a,* }}$, Yujie Zhang ${ }^{\mathrm{a}}$, Zhimin Zhang ${ }^{\mathrm{b}}$, Xiaoke Wang ${ }^{\mathrm{a}}$, Yanju Liu ${ }^{\mathrm{c}}$, Zhenquan Sun ${ }^{\mathrm{c}}$ \\ a Research Center for Eco-Environmental Sciences, Chinese Academy of Sciences, Beijing 100085, China \\ ${ }^{\mathrm{b}}$ East \& West Analytical Instruments, Beijing 100044, China \\ c Beijing Center for Physical and Chemical Analysis, Beijing 100089, China
}

\section{A R T I C L E I N F O}

\section{Article history:}

Received 20 February 2009

Received in revised form 11 September 2009

Accepted 16 September 2009

Available online 8 October 2009

\section{Keywords:}

BTEX

Beijing

Olympic Games and Paralympics

PID

\begin{abstract}
A B S T R A C T
The hourly concentrations of BTEX (Benzene, Toluene, Ethylbenzene, m,p-Xylene and o-Xylene) in the urban area of Beijing were measured during July-October 2008, covering the periods of the 2008 Olympic Games and Paralympic Games. The atmospheric BTEX were pre-concentrated on Tenax-TA tubes, and analyzed by GC-PID (Gas Chromatography with Photo Ionization Detector) after thermal desorption. During the games, the mean daytime concentrations of benzene, toluene, ethylbenzene, m,p-xylene and o-xylene were 2.37, $3.97,1.92,3.51$ and $1.90 \mu \mathrm{g} / \mathrm{m}^{3}$, respectively, and were $52.8 \%, 63.9 \%, 56.4 \%, 56.8 \%$ and $46.9 \%$, respectively lower than those after the games. The significantly positive correlation between BTEX and CO as well as the ratio of benzene/toluene suggested that the vehicle exhaust was the major source of BTEX during the whole investigated period. The extremely high ratios of ethylbenzene to m,p-xylene $(E / X)$ were mainly observed at noontime in haze days, indicating that photochemical reactions were highly active under these typical days.

(C) 2009 Elsevier B.V. All rights reserved.
\end{abstract}

\section{Introduction}

Benzene, Toluene, Ethylbenzene and Xylene (BTEX) are mainly from anthropogenic sources, and vehicle exhaust has been recognized as the dominant source in the atmosphere, followed by gasoline evaporation, emissions from the use of solvents and paintings, leakage from natural gas and liquefied petroleum gas etc. (Liu et al., 2005; Lu et al., 2007; Song et al., 2007). BTEX have become the most abundant component of volatile organic compounds (VOCs) in the atmosphere of most urban areas, and their negative impacts on environmental and public health have already triggered general concern (Mehlman, 1990; Lee et al., 2002; Ras-Mallorquí et al., 2007).

Benzene is characterized as a known human carcinogen (Mehlman, 1990). The other BTEX compounds have also been recognized as neurotoxicity, and possibly produce the symptoms such as tiredness, confusion, weakness, drunken-type actions, memory loss, nausea and loss of appetite (Baker et al., 1985; Mehlman, 1990). BTEX are highly reactive in the troposphere, and hence play an important role in the atmospheric chemistry (Atkinson, 1990). In addition, BTEX have been recognized as the important photochemical precursors for tropospheric ozone and second organic aerosols (Rappenglück and Fabian, 1999; Na et al., 2003; Barletta et al., 2008; Xie et al., 2008; Henze et al., 2008).

To evaluate the impacts of atmospheric BTEX on air quality, the ambient levels of BTEX at rural, suburban, city-center and industrial

\footnotetext{
* Corresponding author. Tel.: +86 10 62849125; fax: +86 1062849117 . E-mail address: yjmu@rcees.ac.cn (Y. Mu).
}

sites in many nations have been investigated (Singh et al., 1985; Derwent et al., 1995; Gee and Sollars, 1998; Rappenglück and Fabian, 1999; Rappenglück et al., 1999; Chan et al., 2002; Lee et al., 2002; Hellén et al., 2003; Na et al, 2003; Ho et al., 2004; Liu et al., 2005; Lu et al., 2007; Ras-Mallorqí et al., 2007; Song et al., 2007; Gros et al., 2007; Barletta et al., 2008; Xie et al., 2008). These measurements provide useful information about the spatial and temporal variations of these compounds, and the ratios of benzene/toluene $(B / T)$ and ethylbenzene/m,p-xylene $(E / X)$ are recognized as useful indicators of atmospheric photochemical activity as well as the sources origination etc. (Nelson and Quigley, 1983; Roberts et al., 1984; Nutmagul and Cronn, 1985).

The continuous increase of energy consumption and explosive growth of vehicle number in Beijing have greatly increased the levels of atmospheric pollutants in recent years (Hao et al., 2005; Hao and Wang, 2005). However, the few measurements focused on AugustSeptember in the campus of Peking University revealed that the concentration of BTEX decreased about 50\% from 2004 to 2006 (Gros et al., 2007; Liu et al., 2005; Lu et al., 2007; Song et al., 2007; Xie et al., 2008). The decrease of the ambient BTEX level in Beijing in recent years may mainly owe to a series of air clean actions adopted by Beijing Municipal government, e.g. the energy from coal has been gradually replaced by natural gas and oil, and the strict emission standard for vehicles has implemented since 1999 (http://web. tongji.edu.cn/ yangdy/sustainable/paper3.htm).

To achieve the goal of "green Olympic Games", more strict air clean actions were adopted by Chinese government (BOCOG, 2005; Hao and Wang, 2005), e.g. odd-even day vehicle operation (with only exception 
for public and special vehicles) was enacted, the production of steel from Shougang Group was reduced to a minimal limit, and the productions of Beijing eastern petrochemical factory and concrete factory etc. were forbidden during the period from 20 July to 20 September, 2008. In addition, the vehicles with exhaust emissions failed to meet the European No.1 standard were all-day forbidden on the roads since 1 July, 2008, and the number of vehicles from the government offices, enterprises in Beijing municipal administrative regions was supposed to decrease more than $70 \%$ of their total vehicles during the period (Liu et al., 2008a). Data from the Beijing Public Security Traffic Management Department and the Beijing Bus Group revealed that the number of automobiles reduced about 1.8 million $(57.7 \%$ of the total vehicle number) every day during the period of odd-even day vehicle operation (Liu et al., 2008a). In the meantime, strict control measures for air pollution from various industrial factories were also carried out in all neighboring provinces and cities (Hebei province, Tianjin City, Shanxi province, Shandong province and Inner Mongolia) (BOCOG, 2005). To evaluate the effect of the control measures, various air pollutants in Beijing were measured by different institutes and universities in China during the two games.

In this study, the hourly average mixing ratios of BTEX at one site in Beijing were continually measured from July 20 to October 20, 2008. To evaluate the effect of the control measures on the atmospheric BTEX, comparisons of the concentrations of BTEX among different periods in 2008 as well as same season investigated in previous years were presented.

\section{Experimental}

\subsection{Sampling site}

Beijing (39.8 N, 116.5 E) is located in the north of China, and surrounded on three sides by mountains. Beijing City covers $16,808 \mathrm{~km}^{2}$ in area with about 15.38 million permanent inhabitants (http://202.84.17.11/english/china_abc/beijing.htm). The number of registered motor-vehicles in Beijing was 3.128 million by the end of 2007, and still increases at a rate of more than $10 \%$ in recent years (Liu et al., 2008a). Vehicle fuels used in Beijing are mainly unleaded gasoline and diesel, and fewer vehicles are using compressed natural gas (CNG) and liquefied petroleum gas (LPG).

Air samples were collected on a rooftop (20 $\mathrm{m}$ above the ground level) in the Research Center for Eco-Environmental Sciences which lies in the north of Beijing City between 4th ring road and 5th ring road (Fig. 1). The sampling site is $4.82 \mathrm{~km}$ away from the Bird's Nest/

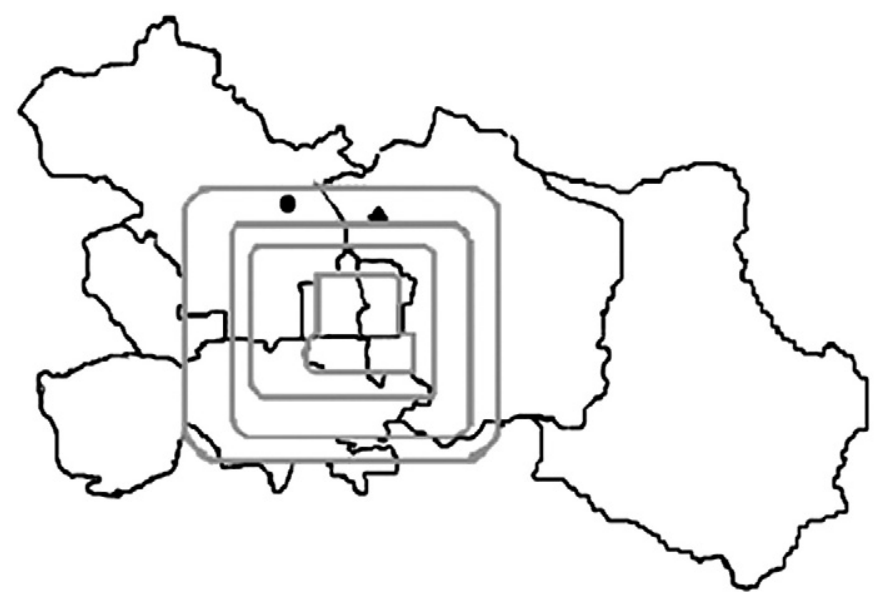

Fig.1. Location of the sampling site in Beijing City, $\mathbf{n}$ is RCEES, — $~$ is the Ring roads and $\Delta$ is the bird's nest.
Olympic Stadium and surrounded by some residential areas, campuses and institutes. Two side roads with moderate traffic flow were about $120 \mathrm{~m}$ away from the sampling site.

\subsection{Sampling and analytical methods}

BTEX in the ambient air was sampled into an absorption tube (15 cm long, $4 \mathrm{~mm}$ ID) filled with Tenax-TA (80-100 mesh, $100 \mathrm{mg}$ ). A portable battery-operated pump (KNF Inc.) was used to drive the air passing through the absorption tube, and the sampling flow rate was controlled via a flow meter with a needle valve to be about $350 \mathrm{~mL} /$ min. To better reflect the hourly average concentrations of BTEX, each sample was collected for 55 min in each hour of the clock time. With only exception for few days, air samples were collected every day from 6:00 to 20:00 during the whole investigation period. Prior to sampling, the absorption tube was conditioned at $350{ }^{\circ} \mathrm{C}$ by passing pure nitrogen gas at a flow of $40 \mathrm{~mL} / \mathrm{min}$ for $30 \mathrm{~min}$ and cooled to room temperature under the same flow of $\mathrm{N}_{2}$. To prevent the accumulation of water in the absorption tube during sampling, the ambient air was first passing through a glass bubbler immersed into an ice-water-salt bath before passing through the absorption tube. Oxidants ( such as $\mathrm{O}_{3}$ etc.) were eliminated via a $\mathrm{Na}_{2} \mathrm{SO}_{3}$ scrubber tube connected to the upstream end of the absorption tube (Goldan et al., 1995).

The pre-concentrated BTEX on the absorption tube were immediately analyzed through thermal desorption followed by gas chromatography equipped with a Photo Ionization Detector (GCPID, GC4400, East \& West Analytical Instruments, Inc.). The thermal desorption was carried out through a thermal desorption unit (GC12A HD-Ш, Shanghai Precision \& Scientific Instrument Co., Ltd) at $300{ }^{\circ} \mathrm{C}$ with a flow rate of $\mathrm{N}_{2}$ of $20 \mathrm{~mL} / \mathrm{min}$ for $4 \mathrm{~min}$. The desorption gas mixture was collected into a $100 \mathrm{~mL}$ glass syringe with a gastight three-valve, and injected into the GC-PID via a six-valve with a Teflon loop of $1.5 \mathrm{~mL}$. BTEX were separated on a capillary column (SE-30 $20 \mathrm{~m} \times 0.5 \mathrm{~mm}$ i.d.), and identified and quantified through an outer standard gas mixture. The operation of GC-PID was controlled by a computer workstation and the column temperature was set to be $50{ }^{\circ} \mathrm{C}$. Total flow rate of the carrier gas (compressed air) was $40 \mathrm{~mL}$ / min, the ratio of injection and split was 1:5.

With only the exception for $\mathrm{m}$ - and p-xylene, other BTEX compounds can be satisfactorily separated on the column. The standard gas mixture of BTEX $\left(\sim 220 \mathrm{mg} / \mathrm{m}^{3}\right.$ for each compound, Center of Standard Reference Materials, Beijing, China) was further diluted with pure $\mathrm{N}_{2}$ to be about $2.20 \mathrm{mg} / \mathrm{m}^{3}$ for each compound, and injected into the GC twice every day before and after air sample measurements for quantifying BTEX concentrations. The daily decrease of the signal for the freshly diluted standard gas mixture was less than $3 \%$ due to the decay of the light intensity of the detector. In addition, a calibration curve with the diluted BTEX standard mixtures (in the range of $0.08-4.50 \mathrm{mg} / \mathrm{m}^{3}$ ) was obtained every week. Good linear correlations between the signals and the concentrations of BTEX were found for these calibration curves with the correlation coefficients $\left(R^{2}\right)$ greater than 0.995 . Relative standard deviations were less than $3 \%$ for all BTEX compounds with 10 injections of a diluted standard BTEX mixture $\left(\sim 1.30 \mathrm{mg} / \mathrm{m}^{3}\right.$ for each). The method detection limit (with a signal-to-noise ratio of 2) for the benzene, toluene, ethylbenzene, m,p-xylene and o-xylene were 0.01, 0.02, 0.06, 0.07 and $0.07 \mu \mathrm{g} / \mathrm{m}^{3}$, respectively. One blank sample was analyzed for each day, and found that the concentrations of BTEX in the blank tube were less than $3 \%$ of those in the ambient air samples. Distinct breakthrough for benzene was found when the absorption tube was kept under ambient air temperature, but greatly improved when the tube was kept in a bath of ice-salt bag. Therefore, all samples were collected under the bath of ice-salt bag, and the collection efficiencies for benzene, toluene, ethylbenzene, m,p-xylene and o-xylene were $81.5 \pm 5.6 \%, 93.6 \pm 2.2 \%, 95.8 \pm 0.8 \%, 96.5 \pm 2.4 \%$ and $91.5 \pm 4.6 \%$ (the 
result of 10 reduplicate experiments with two absorption tubes in series), respectively. The recovery ratios for benzene, toluene, ethylbenzene, m,p-xylene and o-xylene were $95.7 \pm 3.1 \%, 99.2 \pm$ $2.6 \%, 98.6 \pm 2.4 \%, 98.1 \pm 2.4 \%$ and $96.2 \pm 2.2 \%$ (the result of 22 reduplicate experiments), respectively.

Additionally, meteorological data (temperature, relative humidity, wind speed, wind direction, atmospheric pressure and precipitation) and the routine pollutants' data (CO) were recorded by an automatic meteorological station (the Beijing Urban Ecosystem Research Station, RCEES) located at the same site.

\section{Results and discussion}

\subsection{Time series and composition pattern of BTEX}

The time series of daily averaged concentrations for the measured BTEX from 20 July to 20 October are shown in Fig. 2. In general, the variation trends of the BTEX compounds were basically identical during the whole investigation period. The daily variations of BTEX concentrations were too large to be explained by the daily changes of their sources' strength, and hence, meteorological conditions played

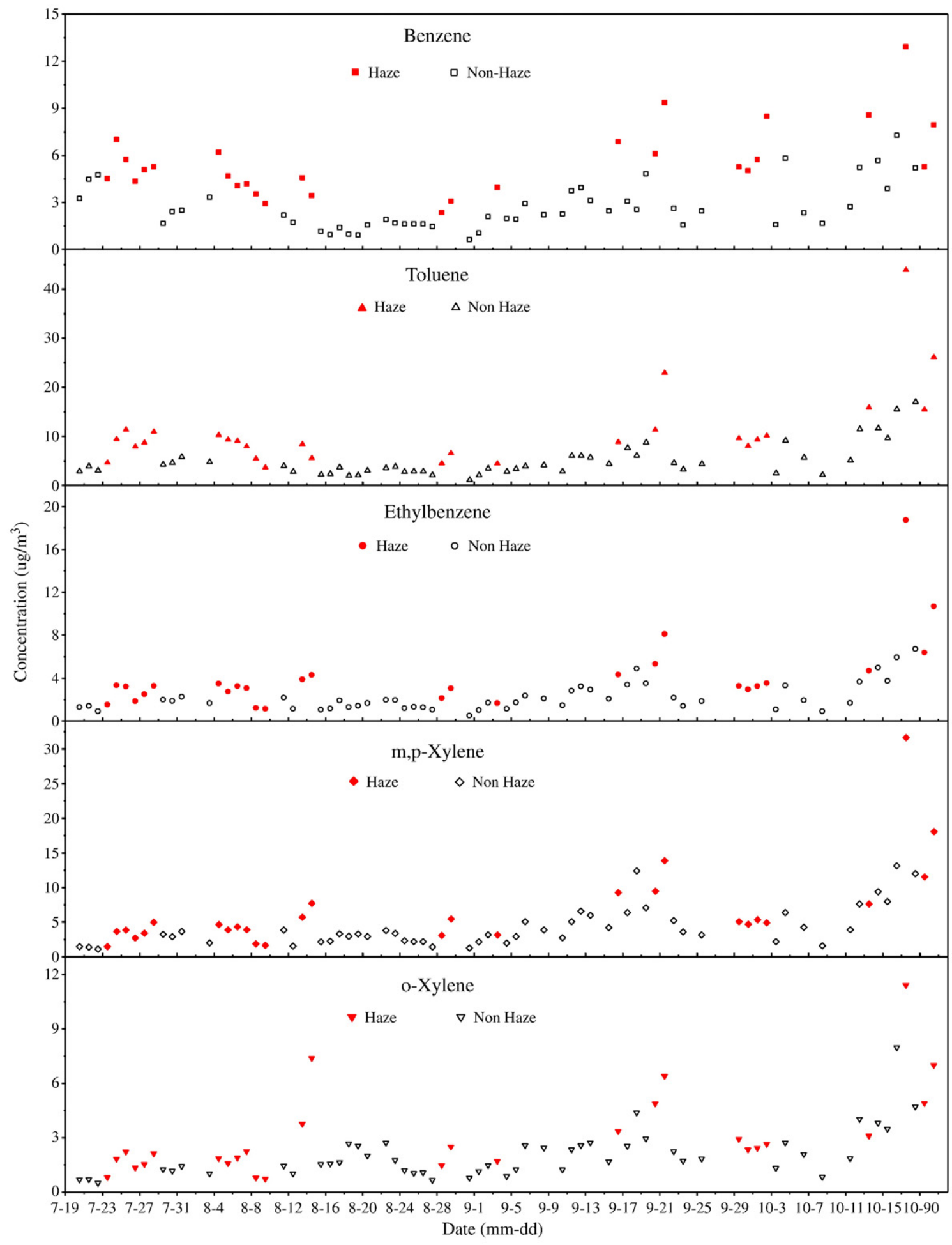

Fig. 2. Time series of daily mean concentration of benzene, toluene, ethylbenzene, m,p-xylene and o-xylene at RCEES during the studied period. 
dominant role on the pollutant levels in Beijing, e.g. extremely high levels of BTEX were usually observed during haze days (with haze duration at least six hours each day) as shown in Fig. 2. Significant negative correlation between BTEX concentrations and wind speed as discussed in section 3.4 also revealed the influence of meteorological conditions on the levels of BTEX.

In order to show the impact of the traffic restriction on atmospheric BTEX in Beijing City, the whole study period was divided into three periods: before the two games (from 20 July to 7 August), during the two games (from 8 August to 17 September) and after the two games (from 18 September to 20 October). It is evident that BTEX concentrations except for xylenes were the lowest during the games, which might partially result from the control measures.

The average concentrations and the variation ranges of BTEX, CO and meteorological parameters at the sampling site in the daytime (from 6:00 to 20:00) during the investigating periods are summarized in Table 1. Compared with the results after the games without the traffic restriction, the average concentrations of BETX (sum) during the traffic restriction period (before and during the two games) decreased about $43.8 \%$ and $57.5 \%$, respectively. These values were in good agreement with the corresponding decrease rates of CO $(31.8 \%$ and $49.7 \%$, respectively) as well as the proportion of the motorvehicles reduction to the total motor-vehicles (57.7\%, Liu et al., 2008a).

The traffic restriction not only reduced the total number of vehicles on road, but also greatly improved the traffic flow status and the structure of vehicles on road, e.g. the motor traffic flow decreased by $32.57 \%$ during the period of the odd-even day vehicle operation, the traffic speed on morning and evening rush hours on the traffic network increased by $26.9 \%$ and $22.8 \%$, respectively, and the number of van, truck and large-sized coach etc. decreased more than 40\% (Liu et al., 2008b). Under this situation, traffic jams were avoided in the road network during the games (Liu et al., 2008b), and pollutants emissions including BTEX must be greatly reduced because the highest pollutants emissions from vehicles commonly happen during traffic jam period when vehicles are under idle state (Cocker et al., 2004).

Compared with the period after the Game, the concentrations of benzene, toluene, ethylbenzene, $\mathrm{m}, \mathrm{p}$-xylene and o-xylene before the games decreased about $12.6 \%, 37.3 \%, 47.3 \%, 62.7 \%$ and $60.9 \%$, respectively, while during the games decreased about $52.8 \%, 63.9 \%$, $56.4 \%, 56.8 \%$ and $46.9 \%$, respectively. The periods before and during the games were under same control measures, the great difference of BTEX concentrations (especially for benzene) between the two period might be attributed to several causes. First, the stagnant air in haze days which frequently happened during the period before the games (haze days accounted for $58.8 \%$ of the total sampling days, Fig. 2) was in favor of pollutants accumulation. Benzene is relatively inert compared with other BTEX, the consumption of benzene due to photochemical reactions should be much less than other BTEX compounds, and hence, magnified the effect of accumulation during these haze days. CO is usually used as an indicator for the emission from vehicle exhaust in urban areas, and the significant difference of $\mathrm{CO}$ decreased rates (as mentioned above) between the two periods also indicated that the weather before the games was in favor of air pollutants accumulation. In addition, the much higher decrease rate of $\mathrm{CO}$ than those of benzene before the games revealed that the sources other than vehicle emission may be responsible for the relatively high concentrations of benzene. Secondly, the new decoration of the old buildings during the period before the games might contribute to atmospheric benzene. Finally, the sources other than vehicular emissions might be also further restricted during the games, but we haven't found any announcement.

It should be mentioned that the concentrations of xylenes during the two games were slightly higher than those before the games. The different photochemical reaction activities during the two periods might be responsible for this phenomenon because of the highest reactivity of xylenes toward $\mathrm{OH}$ radicals among the BTEX compounds (Atkinson, 1990). As mentioned above, high frequency of haze days were met before the games, the high density of particles during haze days can provide enough surface area for the heterogeneous reaction of $\mathrm{NO}_{2}$ with $\mathrm{H}_{2} \mathrm{O}$ to form $\mathrm{HONO}$ which easily produces $\mathrm{OH}$ radicals even under weak sunlight irradiation. Lü et al. (2009) found that the concentrations of formaldehyde and acetaldehyde during haze days were two times higher than those of non-haze days, indicating significant contribution from photochemical reactions of VOCs to formaldehyde and acetaldehyde during haze days. The atmospheric carbonyls were also measured during the period of this study (Xu et al., submitted for publication), and the concentrations of formaldehyde and acetaldehyde during these haze days were also found to be two times higher than those of clear days. The extremely high values and the distinct diurnal variations (with maximal values appeared during noontime and minimal values in the early morning and evening) of ethylbenzene/m,p-xylene ratio in haze days might be a circumstantial evidence for the high photochemical reaction activity (see section 3.5).

The composition patterns denoted as a percent of each BTEX compound to the sum during the three periods are shown in Fig. 3. It is evident that two different patterns appeared during the investigation period. One pattern appeared before the two games, characterized toluene as the most abundant compound followed by benzene. The other pattern appeared during and after the games, characterized toluene as the most abundant compound followed by m,p-xylene. These two typical patterns have also been reported in previous studies

Table 1

A statistical summary of BTEX, CO and meteorological parameters measured during daytime (from 6:00 to 20:00) in the sampling site (from 20 July to 20 October, 2008).

\begin{tabular}{|c|c|c|c|c|}
\hline & $\begin{array}{l}\text { Before }(N=248) \\
(20 / 07-07 / 08)\end{array}$ & $\begin{array}{l}\text { During }(N=422) \\
(08 / 08-16 / 09)\end{array}$ & $\begin{array}{l}\text { After }(N=312) \\
(17 / 09-20 / 10)\end{array}$ & $\begin{array}{l}\text { Total }(N=982) \\
(20 / 07-20 / 10)\end{array}$ \\
\hline \multicolumn{5}{|c|}{ BTEX compound conc. $\left(\mu \mathrm{g} / \mathrm{m}^{3}\right)$} \\
\hline Benzene & $4.39 \pm 1.92$ & $2.37 \pm 1.89$ & $5.02 \pm 4.09$ & $3.72 \pm 3.03$ \\
\hline Toluene & $6.90 \pm 4.68$ & $3.97 \pm 2.56$ & $11.0 \pm 11.9$ & $6.94 \pm 7.86$ \\
\hline Ethylbenzene & $2.32 \pm 1.50$ & $1.92 \pm 1.21$ & $4.40 \pm 4.74$ & $2.81 \pm 3.09$ \\
\hline m,p-xylene & $3.03 \pm 2.30$ & $3.51 \pm 2.45$ & $8.12 \pm 8.71$ & $4.85 \pm 5.74$ \\
\hline o-xylene & $1.40 \pm 1.01$ & $1.90 \pm 1.44$ & $3.58 \pm 3.54$ & $2.31 \pm 2.44$ \\
\hline BTEX & $18.1 \pm 10.4$ & $13.7 \pm 8.54$ & $32.2 \pm 31.1$ & $20.7 \pm 20.8$ \\
\hline \multicolumn{5}{|c|}{ Routine pollutant conc. $\left(\mu \mathrm{g} / \mathrm{m}^{3}\right)$} \\
\hline $\mathrm{CO}$ & $667 \pm 432$ & $492 \pm 496$ & $978 \pm 794$ & $713 \pm 661$ \\
\hline \multicolumn{5}{|c|}{ Meteorological parameters } \\
\hline Temperature $\left({ }^{\circ} \mathrm{C}\right)$ & $28.8 \pm 2.83$ & $25.5 \pm 3.47$ & $19.1 \pm 4.13$ & $24.3 \pm 5.19$ \\
\hline $\mathrm{RH}(\%)$ & $59.8 \pm 14.0$ & $57.1 \pm 15.7$ & $51.0 \pm 20.2$ & $55.8 \pm 17.2$ \\
\hline Wind speed $(\mathrm{m} / \mathrm{s})$ & $1.78 \pm 0.99$ & $1.70 \pm 1.27$ & $1.59 \pm 1.29$ & $1.68 \pm 1.21$ \\
\hline
\end{tabular}




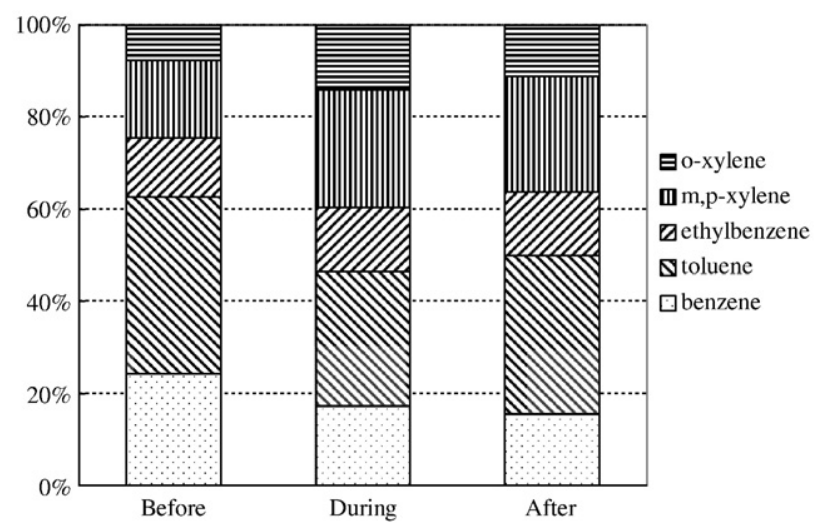

Fig. 3. BTEX composition patterns before, during, and after the two games.

conducted in the urban atmosphere (Singh et al., 1985; Chan et al., 2002; Gros et al., 2007; Barletta et al., 2008; Xie et al., 2008; Derwent et al., 1995; Rappenglück and Fabian, 1999; Lee et al., 2002; Na et al., 2003; Hellén et al., 2003; Ho et al., 2004; Ras-Mallorquí et al., 2007; Song et al., 2007). As mentioned above, the measured xylene concentrations strongly depended on the concentration of atmospheric $\mathrm{OH}$ radicals, and thus the two different patterns might be partially due to the difference of photochemical reaction activity during the two periods.

\subsection{Frequency distribution and comparison with previous studies}

Distribution frequency of pollutant concentrations is a useful statistic method to evaluate the pollution level. Similar pattern of the distribution frequency for each BTEX compound was found during the investigation period. To be simplified, only the distribution frequencies of benzene during the three periods are shown in Fig. 4. Before the games, the distribution frequency of benzene mainly focused on the concentrations from 2 to $6 \mu \mathrm{g} / \mathrm{m}^{3}$, occupied $81.0 \%$ of the total data.
During the games, the distribution frequency of benzene was mainly concentrated in the concentration range of $0-3 \mu \mathrm{g} / \mathrm{m}^{3}$, occupied $77.7 \%$ of the total data. After the two games, the distribution frequency of benzene focused on a broad range $\left(0-9 \mu \mathrm{g} / \mathrm{m}^{3}\right)$, and the frequencies of the concentration higher than $9 \mu \mathrm{g} / \mathrm{m}^{3}$ significantly increased compared with those before and during the games, indicating more serious benzene pollution.

A great number of urban atmospheric BTEX measurements have been reported in the literature. To be simplified for comparison, only the data from the cities in China and several cities in the world once hosted the summer Olympic Games are presented in Table 2. The sampling sites of the three previous studies in Beijing were all in the campus of Peking University where is only about $3.3 \mathrm{~km}$ away from our sampling site (Gros et al., 2007; Song et al., 2007; Xie et al., 2008). It's evident that the concentrations of BTEX measured by this study during the two games were at least $50 \%$ less than theirs as well as the values reported in the other two Chinese cities (Ho et al., 2004; Barletta et al., 2008). Comparison with other cities once hosted the Olympic Games, only with one exception of Helsinki (Hellén et al., 2003), the concentration of BTEX in Beijing City during the two games were the lowest.

It should be mentioned that the fuels used over the world during the last 40 years have changed significantly with the addition of automotive emissions controls systems. For example, in US since 1975 the leaded gasoline was phased out paving the way for unleaded gasoline and multi-generational catalysts which have a significant affect on tail-pipe emissions. Therefore, the above comparison may be unilateral especially for the data reported in the earlier years. Many cities or states in the world have taken great efforts to curtail pollutants including BTEX emissions for improving the urban air quality since 1990s, e.g. the concentrations of urban benzene in Canada and several states in the USA decreased more than 50\% during 1990-2003 (Aleksic et al., 2005).

\subsection{The average diurnal variations of BTEX in Beijing}

The average diurnal variations of BTEX concentrations in Beijing before, during and after the two games are shown in Fig. 5. The

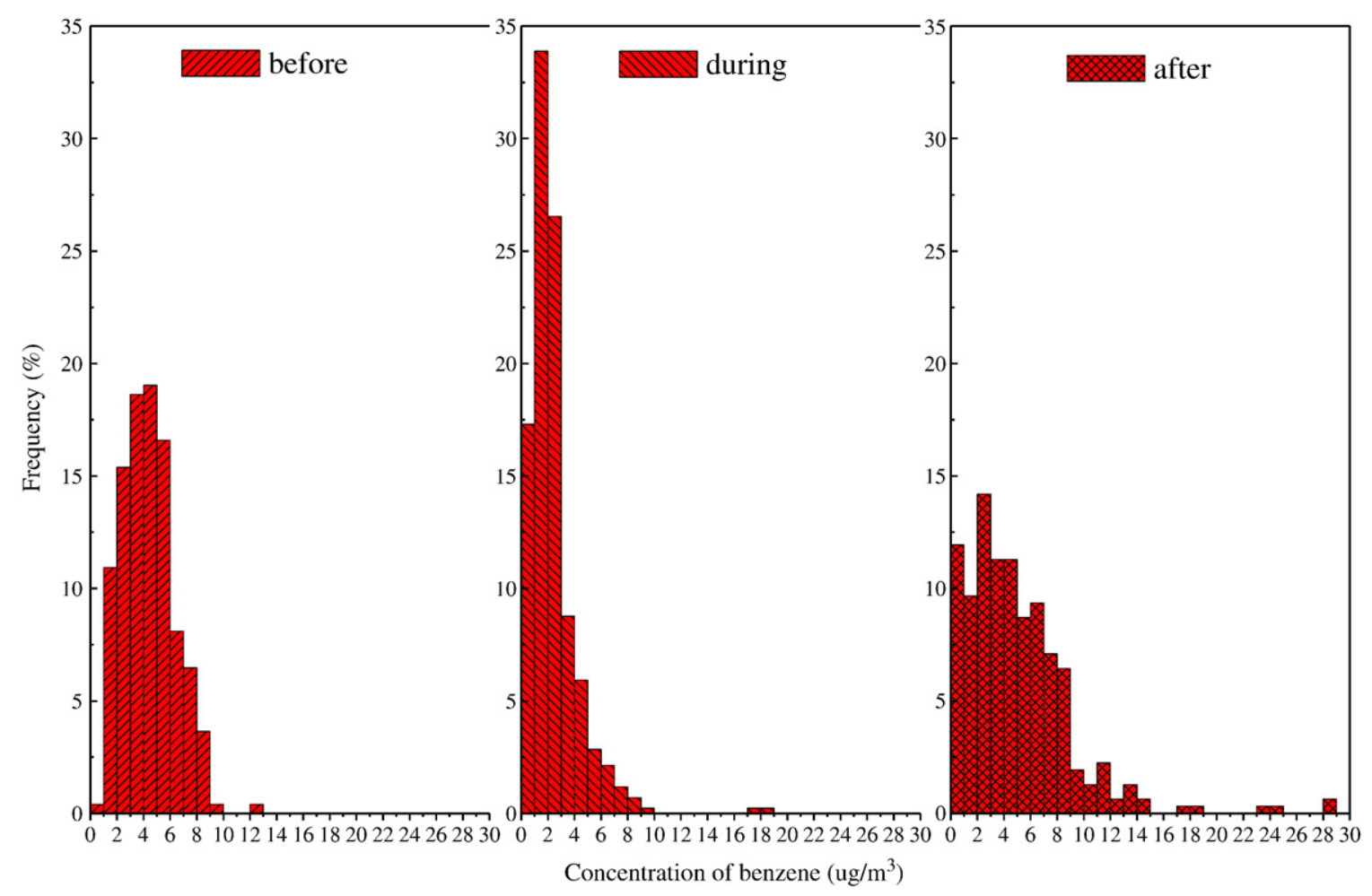

Fig. 4. Frequency distribution of benzene before $(n=248)$, during $(n=422)$ and after $(n=312)$ the Olympic Games and Paralympic Games. 
Table 2

Comparison of levels of BTEX $\left(\mu \mathrm{g} / \mathrm{m}^{3}\right)$ among different cities.

\begin{tabular}{|c|c|c|c|c|c|c|c|c|}
\hline Location & Date & B & $T$ & E & $\mathrm{m}, \mathrm{p}-\mathrm{X}$ & $0-X$ & BTEX & Reference \\
\hline \multicolumn{9}{|l|}{ Beijing City } \\
\hline Beijing & $\begin{array}{l}8-9 / \\
2008\end{array}$ & 2.37 & 3.97 & 1.92 & 3.51 & 1.90 & 13.7 & This work \\
\hline Beijing & $\begin{array}{l}8-9 / \\
2006\end{array}$ & 6.87 & 9.38 & 3.26 & 4.69 & 1.91 & 26.1 & Xie et al. (2008) \\
\hline Beijing & $\begin{array}{l}8 / \\
2005\end{array}$ & 5.62 & 11.4 & 4.26 & 8.86 & 4.04 & 34.2 & $\begin{array}{l}\text { Song et al. } \\
\text { (2007) }\end{array}$ \\
\hline Beijing & $\begin{array}{l}8 / \\
2004\end{array}$ & 13.4 & 16.1 & 5.4 & 12.2 & 2.6 & 49.7 & $\begin{array}{l}\text { Gros et al. } \\
\text { (2007) }\end{array}$ \\
\hline \multicolumn{9}{|c|}{ Other cities in China } \\
\hline Guangzhou & $\begin{array}{l}9 / \\
2005\end{array}$ & 6.55 & 22.1 & 5.38 & 6.68 & 2.47 & 43.2 & $\begin{array}{l}\text { Barletta et al. } \\
\text { (2008) }\end{array}$ \\
\hline Hong Kong & $\begin{array}{l}6-8 / \\
2001\end{array}$ & 2.97 & 26.2 & 3.18 & 3.99 & 3.06 & 39.4 & Ho et al. (2004) \\
\hline \multicolumn{9}{|c|}{ Other cities around the world } \\
\hline Helsinki & $\begin{array}{l}8 / \\
2001\end{array}$ & 1.04 & 3.45 & 0.67 & 1.87 & 0.78 & 7.81 & $\begin{array}{l}\text { Hellén et al. } \\
\text { (2003) }\end{array}$ \\
\hline Athens & $\begin{array}{l}5-6 / \\
1996\end{array}$ & 6.77 & 4.33 & 0.87 & 2.74 & 1.30 & 16.0 & $\begin{array}{l}\text { Rappenglück et } \\
\text { al. (1999) }\end{array}$ \\
\hline St. Louis & $\begin{array}{l}5-6 / \\
1980\end{array}$ & 4.47 & 5.65 & 2.61 & 4.34 & 1.30 & 18.4 & $\begin{array}{l}\text { Singh et al. } \\
\text { (1985) }\end{array}$ \\
\hline Paris & $\begin{array}{l}5 / \\
2005\end{array}$ & 1.45 & 11.1 & 1.50 & 4.70 & 1.60 & 20.4 & $\begin{array}{l}\text { Gros et al. } \\
(2007)\end{array}$ \\
\hline London & $\begin{array}{l}7 / \\
1992\end{array}$ & 9.58 & 17.3 & 3.04 & 10.4 & 3.91 & 44.3 & $\begin{array}{l}\text { Derwent et al. } \\
\text { (1995) }\end{array}$ \\
\hline Munich & $\begin{array}{l}8 / \\
1993\end{array}$ & 9.58 & 21.5 & 5.21 & 12.6 & 4.78 & 53.6 & $\begin{array}{l}\text { Rappenglück } \\
\text { and Fabian } \\
\text { (1999) }\end{array}$ \\
\hline Seoul & $\begin{array}{l}9 / \\
1998\end{array}$ & 5.11 & 48.2 & 7.82 & 16.1 & 6.51 & 83.8 & Na et al. (2003) \\
\hline Los Angeles & $\begin{array}{l}4 / \\
1979\end{array}$ & 19.2 & 44.1 & 9.99 & 20.0 & 8.25 & 101.5 & $\begin{array}{l}\text { Singh et al. } \\
\text { (1985) }\end{array}$ \\
\hline
\end{tabular}

Note: $B$ : benzene; $T$ : toluene; $E$ : ethylbenzxen; m,p-X: m,p-xylene; o-X: o-xylene; BTEX: sum of benzene, toluene, ethylbenzene, $\mathrm{m}$,p-xylene and o-xylene. common character of the diurnal variations during the three periods was the valley value in the afternoon (around 15:00 h), which was probably due to the relative low traffic flow, the meteorological condition (such as the elevation of the boundary layer etc.), and the photochemical consumption of BTEX etc. Comparison with the periods before and during the two games, two distinct peak values after the games appeared during the two traffic rush hours in the early morning (6:00-9:00) and late afternoon (17:00-20:00). As mentioned above, traffic congestion can emit more pollutants than smooth traffic (Cocker et al., 2004), and the two distinct peak values after the games might be a circumstantial evidence. A new traffic restriction policy (every weekday $20 \%$ of private cars were forbidden and the forecasted reduction of the traffic flow was about 10\%) in Beijing has brought into effect since October 20, 2008, which may play an important role on improving the traffic flow status and the air quality in Beijing City.

\subsection{The correlations among BTEX and other parameters}

Correlation analysis among different pollutants can provide useful information about the sources origination, and hence the data of this study were analyzed through the Pearson correlation method and presented in Table 3. In general, significant positive correlation coefficients among BTEX compounds and CO were found during the whole period of investigation. Because $\mathrm{CO}$ is usually considered as a typical indicator for the vehicle exhaust in urban areas, the relative high correlation coefficient between each BTEX compound and CO indicated traffic emission was an important source for the atmospheric BTEX in Beijing City. The significant correlations among BTEX concentrations, wind speed, temperature and relative humidity also reflected the strong influence of the meteorological condition on the atmospheric BTEX.

The significantly negative correlations between wind velocity and pollutant levels were due to the faster diffusion of pollutants promoted by winds. However, no significant difference about the mean wind speed (Table 1) was found among the three investigated periods, and hence, only wind speed couldn't account for the large
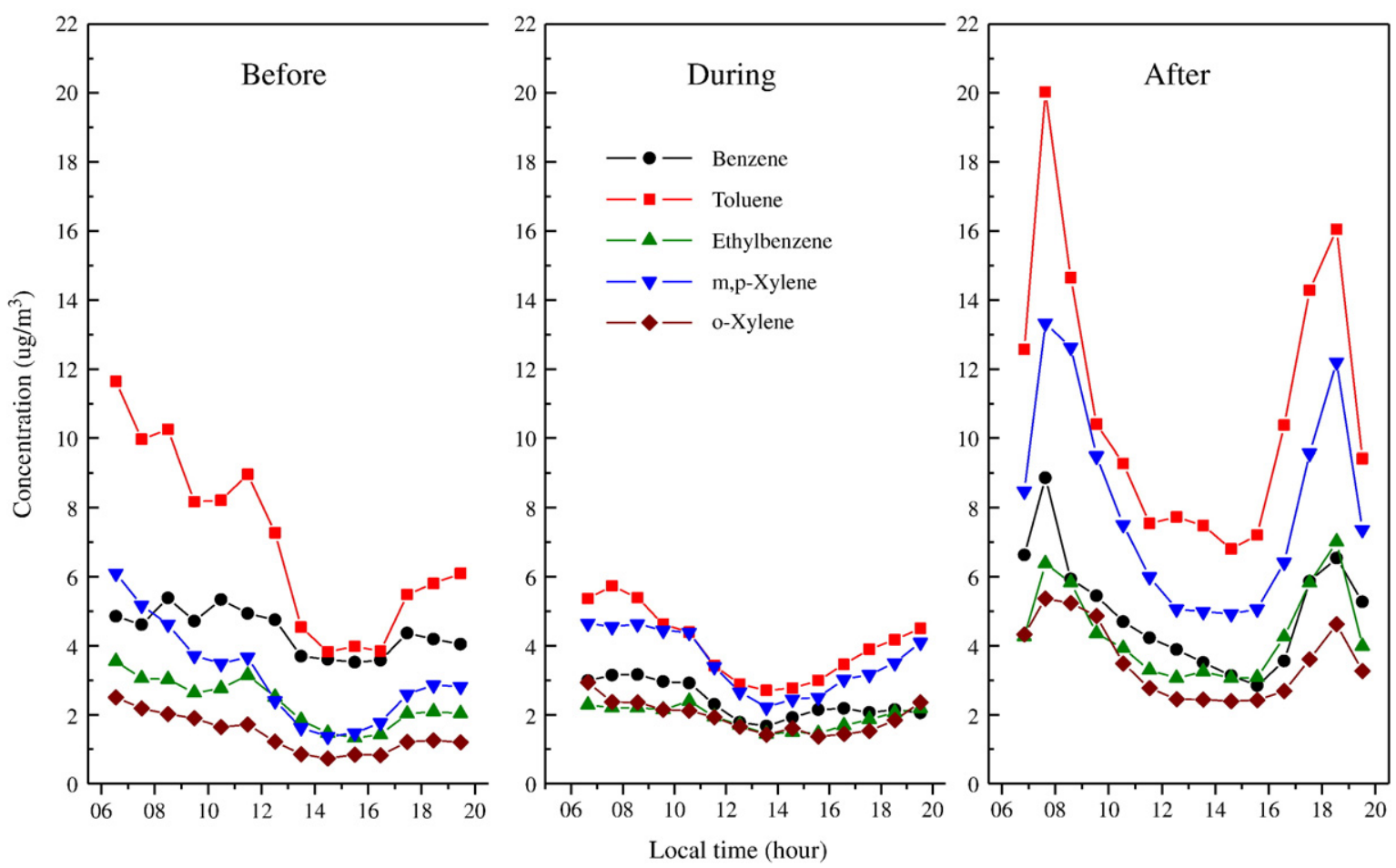

Fig. 5. The diurnal variations of the hourly averaged BTEX concentrations in Beijing before, during and after the Olympic Games and Paralympic Games. 
Table 3

Pearson correlation coefficients between BTEX, CO and meteorology.

\begin{tabular}{|c|c|c|c|c|c|}
\hline & Benzene & Toluene & Ethylbenzene & m,p-xylene & o-xylene \\
\hline \multicolumn{6}{|c|}{ Before the Olympic Games and Paralympic Games $(20 / 07-07 / 08, N=248)$} \\
\hline Benzene & 1 & & & & \\
\hline Toluene & $0.674^{* *}$ & 1 & & & \\
\hline Ethylbenzene & $0.582^{* *}$ & $0.897^{* *}$ & 1 & & \\
\hline m,p-xylene & $0.430^{* *}$ & $0.879^{* *}$ & $0.922^{* * *}$ & 1 & \\
\hline o-xylene & $0.485^{* *}$ & $0.857^{* *}$ & $0.901^{* *}$ & $0.912^{* *}$ & 1 \\
\hline Temperature & 0.071 & $-0.343^{* *}$ & $-0.381^{* *}$ & $-0.582^{* *}$ & $-0.477^{* *}$ \\
\hline Humidity & $0.152^{*}$ & $0.485^{* *}$ & $0.479^{* *}$ & $0.615^{* *}$ & $0.542^{* *}$ \\
\hline Wind speed & $-0.164^{* *}$ & $-0.296^{* *}$ & $-0.244^{* *}$ & $-0.234^{* *}$ & $-0.221^{* *}$ \\
\hline $\mathrm{CO}$ & $0.770^{* *}$ & $0.721^{* *}$ & $0.670^{* *}$ & $0.547^{* *}$ & $0.644^{* *}$ \\
\hline \multicolumn{6}{|c|}{ During the Olympic Games and Paralympic Games $(08 / 08-16 / 09, N=422)$} \\
\hline Benzene & 1 & & & & \\
\hline Toluene & $0.813^{* *}$ & 1 & & & \\
\hline Ethylbenzene & $0.715^{* *}$ & $0.840^{* *}$ & 1 & & \\
\hline m,p-xylene & $0.701^{* *}$ & $0.786^{* *}$ & $0.935^{* *}$ & 1 & \\
\hline o-xylene & $0.427^{* *}$ & $0.537^{* *}$ & $0.765^{* *}$ & $0.802^{* *}$ & 1 \\
\hline Temperature & $-0.214^{* *}$ & $-0.332^{* *}$ & $-0.322^{* *}$ & $-0.418^{* *}$ & $-0.300^{* *}$ \\
\hline Humidity & $0.372^{* *}$ & $0.486^{* *}$ & $0.406^{* *}$ & $0.408^{* *}$ & $0.359^{* *}$ \\
\hline Wind speed & $-0.145^{* *}$ & $-0.230^{* *}$ & $-0.182^{* *}$ & $-0.175^{* *}$ & $-0.150^{* *}$ \\
\hline $\mathrm{CO}$ & $0.770^{* *}$ & $0.713^{* *}$ & $0.587^{* *}$ & $0.573^{* *}$ & $0.411^{* *}$ \\
\hline \multicolumn{6}{|c|}{ After the Olympic Games and Paralympic Games $(17 / 09-20 / 10, N=312)$} \\
\hline Benzene & 1 & & & & \\
\hline Toluene & $0.864^{* *}$ & 1 & & & \\
\hline Ethylbenzene & $0.735^{* *}$ & $0.934^{* *}$ & 1 & & \\
\hline m,p-xylene & $0.704^{* *}$ & $0.884^{* *}$ & $0.958^{* *}$ & 1 & \\
\hline o-xylene & $0.644^{* *}$ & $0.759^{* *}$ & $0.848^{* *}$ & $0.927^{* *}$ & 1 \\
\hline Temperature & $-0.308^{* *}$ & $-0.248^{* *}$ & $-0.143^{*}$ & $-0.187^{*}$ & $-0.208^{*}$ \\
\hline Humidity & $0.453^{* *}$ & $0.306^{* *}$ & $0.260^{* *}$ & $0.250^{* *}$ & $0.238^{* *}$ \\
\hline Wind speed & $-0.372^{* *}$ & $-0.304^{* *}$ & $-0.264^{* *}$ & $-0.268^{* *}$ & $-0.268^{* *}$ \\
\hline $\mathrm{CO}$ & $0.769^{* *}$ & $0.656^{* *}$ & $0.574^{* *}$ & $0.507^{* *}$ & $0.445^{* *}$ \\
\hline
\end{tabular}

$\mathrm{N}$ : number of samples in statistical analysis.

** Correlation is significant at the 0.01 levels.

* Correlation is significant at the 0.05 levels.

difference of BTEX concentrations among the three periods. No obvious correlation between wind direction and the concentration of BTEX (data not shown) suggested that the concentrations of BTEX measured at the sampling site could represent the status of larger area in Beijing City. In addition, 40 samples were sampled in small rain events of 18 days during the whole measurement period. Because BTEX compounds are insoluble, no significant change of BTEX concentration was found before, during and after the rain events.

\subsection{The ratios among BTEX}

The benzene/toluene $(B / T)$ ratio is widely used as an indicator for vehicle exhaust in the urban areas because of the significant difference of the ratios between the vehicle exhaust and other sources, such as painting and gasoline etc (Sweet and Vermette, 1992; Baldasano et al., 1998; Song et al., 2007). A B/T ratio of around 0.5 (wt/ wt) has been reported to be characteristic of vehicular emissions (Sweet and Vermette, 1992; Scheff and Wadden, 1993; Perry and Gee, 1995; Baldasano et al., 1998). In order to verify if this ratio could be applied to the Chinese vehicular fleet, Barletta et al. (2005) investigated 27 roadside samples from 25 different cities, and an average value of 0.6 (wt/wt) $(\sigma=0.2)$ was obtained. Liu et al. (2005) also reported the $B / T$ ratio was 0.61 from roadside in Beijing. The average ratios of $B / T$ measured in Beijing before, during and after the two games were $0.64,0.60$ and 0.46 , respectively. These values were within the reported range (as shown in Table 4), and close to 0.6 from the Chinese vehicle exhaust (Barletta et al., 2005; Liu et al., 2005), indicating vehicular emission as the main source of benzene and toluene in Beijing during the investigated period.

Compared with the period after the two games, the $B / T$ ratios were significant high during the early two periods. The main reason might
Table 4

Comparison of the benzene/toluene $(B / T)$ and m,p-xylene/ethylbenzene $(E / X)$ ratios in different cities.

\begin{tabular}{lllll}
\hline Location & Date & $B / T$ & $E / X$ & Reference \\
\hline Beijing & $07-08 / 2008$ & 0.64 & 0.77 & This work \\
Beijing & $08-09 / 2008$ & 0.60 & 0.55 & This work \\
Beijing & $09-10 / 2008$ & 0.46 & 0.54 & This work \\
Beijing & $08 / 2004$ & 0.83 & 0.44 & Gros et al. (2007) \\
Beijing & $08 / 2005$ & 0.49 & 0.48 & Song et al. (2007) \\
Beijing & $08-09 / 2006$ & 0.73 & 0.70 & Xie et al. (2008) \\
Guangzhou & $09 / 2005$ & 0.30 & 0.81 & Barletta et al. (2008) \\
Hong Kong & $06-08 / 2001$ & 0.11 & 0.80 & Ho et al. (2004) \\
Helsinki & $08 / 2001$ & 0.30 & 0.36 & Hellén et al. (2003) \\
Athens & $05-06 / 1996$ & 1.56 & 0.32 & Rappenglück et al. (1999) \\
St. Louis & $05-06 / 1980$ & 0.79 & 0.60 & Singh et al. (1985) \\
Paris & $05 / 2005$ & 0.13 & 0.32 & Gros et al. (2007) \\
London & $07 / 1992$ & 0.55 & 0.29 & Derwent et al. (1995) \\
Munich & $08 / 1993$ & 0.45 & 0.41 & Rappenglück and Fabian (1999) \\
Seoul & $09 / 1998$ & 0.11 & 0.49 & Na et al. (2003) \\
Los Angeles & $04 / 1979$ & 0.44 & 0.50 & Singh et al. (1985) \\
\hline
\end{tabular}

be due to the variation of the proportion of different sources during the investigated period. As mentioned above, the out-wall decoration of the older buildings might contribute to the atmospheric benzene during the early two periods. In addition, the traffic restriction was mainly for private cars which use gasoline as fuel, and hence, the proportion of public vehicles, such as public bus which mainly use diesel as fuel, increased correspondingly. Compared with the base survey period, the ratio of passenger cars on expressway declined from $66.53 \%$ to $50.85 \%$ during the games, however, the ratio of buses increased from $3.23 \%$ to $6.08 \%$ (Liu et al., 2008a).

The ratio of ethylbenzene/m,p-xylene $(E / X)$ is usually used as the photochemical reactivity indicator, because m,p-xylene and ethylbenzene are usually from common sources in the urban atmosphere and the rate constant of $\mathrm{m}, \mathrm{p}$-xylene with $\mathrm{OH}$ radicals is about 3 times faster than that of ethylbenzene (Atkinson, 1990; Nelson and Quigley, 1983). The average ratios of $E / X$ measured in this study before, during and after the two games were $0.77,0.55$ and 0.54 , respectively. These values were in the range $(0.29-0.81)$ of those reported in the literature as listed in Table 4 . The large variation range of $E / X$ ratios reported in the literature was partially due to the different $E / X$ ratios of the original sources from the various cities. Photochemical reactions also made great contribution to the $E / X$ ratio, e.g. the $E / X$ ratios obtained by this study and the three previous studies (0.44$0.70)$ in Beijing City were significant higher than those from the dominant sources (e.g. the $E / X$ ratio from vehicle exhaust is only about 0.3 , Liu et al., 2005). The distinct diurnal variations of $E / X$ ratio as shown in Fig. 6 evidently revealed the contribution of photochemical reactions to $E / X$ ratio. To distinguish the photochemical activities under different weather conditions, the weather conditions were

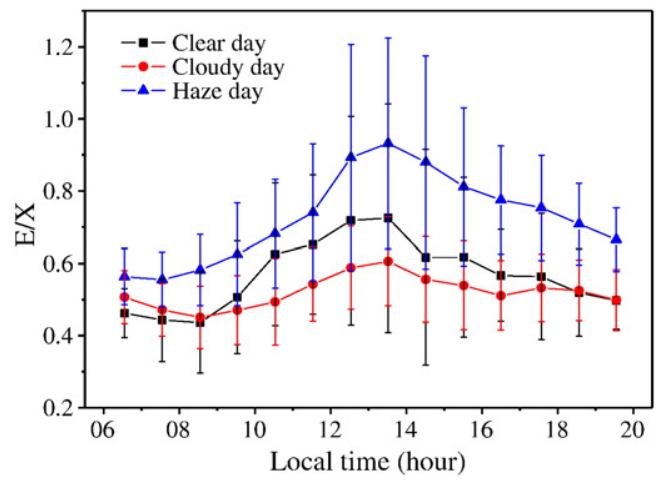

Fig. 6. The averaged diurnal variations of ethylbenzene/m,p-xylene under the days with different weather conditions ( $\bullet$ : cloudy days; $\mathbf{\square}$ : clear days; $\mathbf{\Delta}$ : haze days). 
roughly classified into three groups: the haze days (28 days), the typical clear days (10 days) and cloudy days ( 9 days). It is evident that the photochemical activity during haze days was the most pronounced among the three typical weather conditions. As mentioned in the section 3.1, high concentration of $\mathrm{OH}$ radicals might be formed due to the heterogeneous reaction of $\mathrm{NO}_{2}$ with $\mathrm{H}_{2} \mathrm{O}$ under the typical haze days frequently happened before the games, and resulted in much higher value of $E / X$ during this period than that during the other two periods.

\section{Conclusions}

Evident decrease (at least 50\%) in atmospheric BTEX concentrations in Beijing City was observed during the period of the two games, which may have resulted from the control measures adopted by Chinese government. The analysis of the correlations among the BTEX compounds and $\mathrm{CO}$ as well as the ratio of $B / T$ indicated that BTEX and $\mathrm{CO}$ were mainly from common sources, and the vehicle exhaust might be the dominant one. The extremely high value of $E / X$ ratio during haze days implied that the photochemical reactions were highly active during these typical days in Beijing.

The extensive control measures adopted by Chinese government for the two games may be effective for improving the air quality in Beijing City, but it is unpractical for long term execution. Although the new traffic restriction policy (about $10 \%$ restriction) in Beijing City has brought into effect since October 20, 2008, the number of cars increases at fast rate $(\sim 10 \%)$ in recent years in the big city, and hence, the atmospheric pollutants due to the vehicular emissions in Beijing City will soon recover or even become more serious. Referring to the regulatory health risks limit of the European Union for Benzene, there are still arduous tasks for Beijing government to improve the air quality in the megalopolis.

\section{Acknowledgements}

This work was financially supported by the Chinese National Natural Science Foundation (20977097, 40830101, 40875082 and 20577064), the Chinese Academy of Sciences (KZCX2-YW-Q02-03), the Platform Construction of Introducing Central Resources in Beijing (PXM2008_178305_06995) and the National Basic Research and Development Program 973 (2010CB732304, 2005CB422201).

\section{References}

Aleksic N, Boynton G, Sistla G, Perry J. Concentrations and trends of benzene in ambient air over New York State during 1990-2003. Atmos Environ 2005;39:7894-905.

Atkinson R. Gas-phase tropospheric chemistry of organic compounds: a review. Atmos Environ 1990;24A:1-41.

Baker EL, Smith TJ, Landrigan PJ. The neurotoxicity of industrial solvents: a review of the literature. Am J Ind Med 1985;8:207-17.

Baldasano JM, Delgado R, Calbó J. Applying receptor models to analyze urban/suburban VOCs air quality in Martorell (Spain). Environ Sci Technol 1998;32:405-12.

Barletta B, Meinardi S, Rowland FS, Chan CY, Wang XM, Zou SC, et al. Volatile organic compounds in 43 Chinese cities. Atmos Environ 2005;39:5979-90.

Barletta B, Meinardi S, Simpson IJ, Zou SC, Rowland FS, Blake DR. Ambient mixing ratios of nonmethane hydrocarbons (NMHCs) in two major urban centers of the Pearl River Delta (PRD) region: Guangzhou and Dongguan. Atmos Environ 2008;42:4393-408.

Beijing Organizing Committee for the Games of the XXIX Olympic Games (BOCOG). Green Olympics in Beijing; 2005. http://en.beijing2008.cn/bocog/environment/ guidelines/ n214068405.shtml.

Chan CY, Chan LY, Wang XM, Liu YM, Lee SC, Zou SC, et al. Volatile organic compounds in roadside microenvironments of metropolitan Hong Kong. Atmos Environ 2002;36:2039-47.
Cocker WDR, Shah SD, Johnson KC, Zhu XN, Miller JW, Norbeck JM. Development and application of a mobile laboratory for measuring emissions from diesel engines. 2. Sampling for toxics and particulate matter. Environ Sci Technol 2004;38:6809-16.

Derwent RG, Middleton DR, Field RA, Goldstone ME, Lester JN, Perry R. Analysis and interpretation of air quality data from an urban roadside location in Central London over the period from July 1991 to July 1992. Atmos Environ 1995;29:923-46.

Gee IL, Sollars CJ. Ambient air levels of volatile organic compounds in Latin American and Asian cities. Chemosphere 1998;36:2497-506.

Goldan PD, Kuster WC, Fehsenfeld FC, Montzka SA. Hydrocarbon measurements in the southeastern United States: the rural oxidants in the southern environment (ROSE) program 1990. J Geophys Res 1995;100:25945-63.

Gros V, Sciare J, Yu T. Air-quality measurements in megacities: focus on gaseous organic and particulate pollutants and comparison between two contrasted cities, Paris and Beijing. C r Geosci 2007;339:764-74.

Hao JM, Wang LT. Improving urban air quality in China: Beijing case study. J Air Waste Manage Assoc 2005;55:1298-305.

Hao JM, Wang LT, Li L, Hu JN, Yu XC. Air pollutants contribution and control strategies of energy-use related sources in Beijing. Sci China Ser D-Earth Sci 2005;48(Supp. II):138-46.

Hellén $H$, Hakola $H$, Laurila T. Determination of source contributions of NMHCs in Helsinki $\left(60^{\circ} \mathrm{N}, 25^{\circ} \mathrm{E}\right)$ using chemical mass balance and the Unmix multivariate receptor models. Atmos Environ 2003;37:1413-24.

Henze DK, Seinfeld JH, Ng NL, Kroll JH, Fu TM, Jacob DJ, et al. Global modeling of secondary organic aerosol formation from aromatic hydrocarbons: high- vs. low-yield pathways. Atmos Chem Phys 2008;8:2405-21.

Ho KF, Lee SC, Guo H, Tsai WY. Seasonal and diurnal variations of volatile organic compounds (VOCs) in the atmosphere of Hong Kong. Sci Total Environ 2004;322:155-66.

Lee SC, Chiu MY, Ho KF, Zou SC, Wang XM. Volatile organic compounds (VOCs) in urban atmosphere of Hong Kong. Chemosphere 2002;48:375-82.

Liu MJ, Mao BH, Huang Y, Zhang JP, Chen SK. Comparison of Pre- \& Post-Olympic traffic: a case study of several roads in Beijing. J Trans Syst Eng Inf Technol 2008a;8:67-72.

Liu XM, Guo JF, Sun ZZ. Traffic operation with comments during Beijing Olympic Games. J Trans Syst Eng Inf Technol 2008b;8:16-24.

Liu Y, Shao M, Zhang J, Fu LL, Lu SH. Distributions and source apportionment of ambient volatile organic compounds in Beijing City, China. J Environ Sci Health Part A Toxic Hazard Subst Environ Eng 2005;40:1843-60.

Lü HX, Wen S, Sheng GY, Fu JM. Low-molecular-weight carbonyl compounds in ambient air during haze and non-haze periods in Guangzhou, China. Environ Chem 2009;28:562-6 (in Chinese)

Lu SH, Liu Y, Shao M, Huang S. Chemical speciation and anthropogenic sources of ambient volatile organic compounds (VOCs) during summer in Beijing, 2004. Front Environ Sci Eng China 2007;1:147-52.

Mehlman MA. Dangerous properties of petroleum-refining products: carcinogenicity of motor fuels (gasoline). Teratog Carcinog Mutagen 1990;10:399-408.

Na K, Kim YP, Moon KC. Diurnal characteristics of volatile organic compounds in the Seoul atmosphere. Atmos Environ 2003;37:733-42.

Nelson PF, Quigley SM. The m, p-xylenes: ethylbenzene ratio, a technique for estimating hydrocarbon age in ambient atmospheres. Atmos Environ 1983:17:659-62.

Nutmagul W, Cronn DR. Determination of selected atmospheric aromatic hydrocarbons at remote continental and oceanic locations using Photoionization/Flame -Ionization Detection. J Atmos Chem 1985;2:415-33.

Perry R, Gee IL. Vehicle emissions in relation to fuel composition. Sci Total Environ 1995;169:149-56

Rappenglück B, Fabian P. Nonmethane hydrocarbons (NMHC) in the Greater Munich Area/Germany. Atmos Environ 1999;33:3843-57.

Rappenglück B, Kourtidis K, Melas D, Fabian P. Observations of biogenic and anthropogenic NMHC in the Greater Athens Area During the PAUR Campaign Phys Chem Earth Part B Hydrol Oceans Atmos 1999;24:717-24.

Ras-Mallorquí MR, Marcé-Recasens RM, Borrull-Ballarín F. Determination of volatile organic compounds in urban and industrial air from Tarragona by thermal desorption and gas chromatography-mass spectrometry. Talanta 2007:72:941-50.

Roberts JM, Fehsenfeld FC, Liu SC, Bollinger MJ, Hahn C, Albritton DL, et al. Measurements of aromatic hydrocarbon ratios and NOx concentrations in the rural troposphere: observation of air mass photochemical aging and NOx removal. Atmos Environ 1984;18:2421-32.

Scheff PA, Wadden RA. Receptor modeling of volatile organic compounds. 1. Emission inventory and validation. Environ Sci Technol 1993;27:617-25.

Singh HB, Salas LJ, Cantrell BK, Redmond RM. Distribution of aromatic hydrocarbons in the ambient air. Atmos Environ 1985;19:1911-9.

Song Y, Shao M, Liu Y, Lu SH, Kuster W, Goldan P, et al. Source apportionment of ambient volatile organic compounds in Beijing. Environ Sci Technol 2007;41:4348-53.

Sweet CW, Vermette SJ. Toxic volatile organic compounds in urban air in Illinois. Environ Sci Technol 1992;26:165-73.

Xie X, Shao M, Liu Y, Lu SH, Chang CC, Chen ZM. Estimate of initial isoprene contribution to ozone formation potential in Beijing, China. Atmos Environ 2008:42:6000-10.

Xu Z., Mu Y. J., Liu J.F., Zhang Y. J., Liang P., The ambient air levels of carbonyls in Beijing during the 2008 Olympic Games. Atmospheric Environment, submitted for publication. 